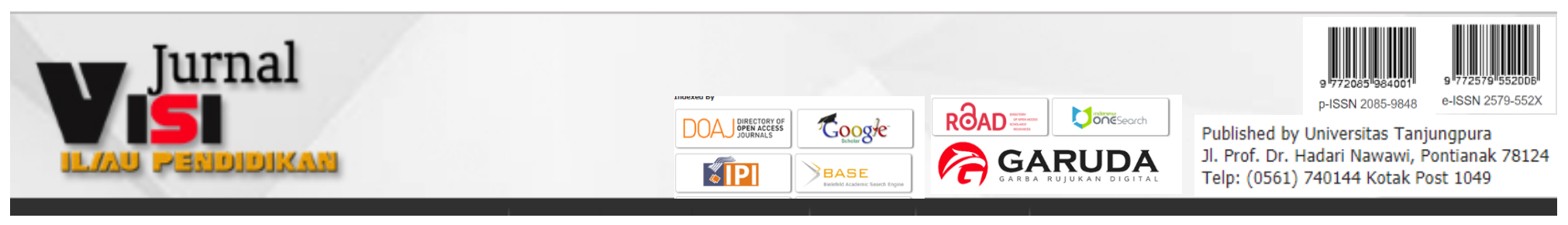

\title{
MANAJEMEN MUTU LAYANAN PADA SEKOLAH MENENGAH
}

\author{
M. Chiar \\ FKIP Universitas Tnjungpura, Pontianak \\ Email:chiar233@ymail.com
}

\begin{abstract}
Abstrac
Mutu layanan akan berhasil dalam mencapa itujuannya jika konsumen merasakan kepuasan yang sangat tinggi,dengan kata lain keberhasilan mutu layanan sangat tergantung pada konsumen atau pelanggan dalam arti lembaga yang bermutu selalu memberikan kepuasan kepada pelanggannya. Karena mutu layanan berpusat pada upaya pemenuhan kebutuhan dan keinginan pelanggan serta ketepatan penyampai nya untuk mengimbangi harapan pelanggan. Sehubungan dengan itu maka tujuan dalam penelitian ini adalah untuk mendapatkan informasi tentang perencanaan mutu pelayanan, pelaksanaan mutu, pengendalian mutu layanan, perbaikan mutu layanan serta apa saja yang menjadi hambatan dalam memberikan pelayanan di SMA Negeri 1 Sungai Ambawang. Penelitian ini menggunakan metode deskriptif dengan pendekatan kualitatif. Jenis penelitian ini adalah case studi (studi kasus) dengan melakukan secara eksploratif yang bersifat mendalam dengan menganalisis apa yang sebenarnya terjadi di balik fakta atau kasus. Alat pengumpul datanya dengan melakukan wawancara, dekomentasi dan panduan observasi. Selanjutnya untuk analisis data digunakan langlah-langkah yang dibagi dalam tiga bagian yaitu; data reduction, data display dan conclution/verification. Setelah diadakan penelitian, maka didapatkan temuantemuan sebagai berikut: Perencanaan mutu layanan yang dilaksanakan di Sekolah Menengah Atas Negeri (SMA Negeri) 1 Sungai Ambawang telah menggambarkan pola yang baik yaitu dengan melibatkan guru dengan cara mengajak guru membuat program bagi yang ingin berpartisipasi. Pelaksanaan mutu layanan oleh kepala sekolah sudah sesuai dengan program yang dibuat sebelumnya, meskipun masih ada program yang belum terlaksana atau belum tercapai. Pengendalian mutu layanan yang dilaksanakan oleh kepala sekolah sudah cukup efektif. Perbaikan mutu layanan telah dilakukan oleh kepala sekolah secara terus menerus terutama yang berhubungan dengan proses pembelajaran.
\end{abstract}

Keyword : Service Quality

\section{PENDAHULUAN}

Pendidikan yang dilaksanakan pada suatu lembaga khususnya sekolah akan menjadi baik bilamana lembaga tersebut memberikan pelayanan yang baik pula. Pelayanan yang baik adalah pelayanan yang bermutu maksudnya pelayanan yang selalu memenuhi kebutuhan dan kepuasan pelanggan. Dengan demikian pelayanan mutu pendidikan merupakan pelayanan yang berpusat pada pemenuhan dan keinginan pelanggan yaitu warga sekolah. Oleh karena itu keberhasilan sekolah dalam mencapai tujuannya harus beroirentasi pada mutu.

Mutu pada suatu lembaga pendidikan merupakan paduan sifat-sifat layanan yang diberikan yang menyamai atau melebihi harapan serta kepuasan pelanggan. Dengan demikian dapat dikatakan bahwa mutu layanan adalah upaya yang dilakukan dengan memberikan kepuasan atau memenuhi harapan kepada pelanggan pada suatu lembaga pendidikan. Mutu layanan sangat penting bagi setiap lembaga pendidikan sebagaimana dikatakan oleh Dewi Sartika (2002;93) "Jaminan kualitas pada hakekatnya berhubungan dengan bagaimana menentukan dan menyampaikan apa yang dipromosikan kepada konsumen, lebih dari itu kita telah memulai untuk memperbaiki proses penentuan apa yang pelanggan inginkan untuk merancang kualitas produksi dan prosesnya menggunakan metode seperti penyebaran fungsi kualitas (Quality Function Development). Dengan

website: http://jurnal.untan.ac.id/index.php/jvip email: jurnalvisi@untan.ac.id 
demikian mutu pelayanan dalam pendidikan sangat penting agar konsumen (pelanggan) memperoleh kepuasan layanan dari jasa pendidikan yang diberikan lembaganya,

Mutu pendidikan berkait erat dengan proses pendidikan. Tanpa proses pelayanan pendidikan yang bermutu tidak mungkin diperoleh produk layanan yang bermutu, dengan kata laintidak akan ada kepuasan pelanggan (para guru dan masyarakat).

Kepuasan pelanggan mencakup adanya perbedaan antara tingkat kepentingan dan kinerja yang ada dengan hasil yang akan diharapkan dan dirasakannya. Kepuasan pelanggan mencakup perbedaan antara harapan dan kinerja atau hasil yang diharapkan. Jika di sini kinerja tidak mencukupi harapan, maka pelanggan akan merasa tidak puas. Aritonang (2005) berpendapat bahwa kepuasan pelanggan yang diartikan sebagai hasil penilaian pelanggan terhadap apa yang diharapkannya dengan membeli dan mengonsumsi suatu produk.

Ada dua ukuran mengenai kepuasan pelanggan yaitu: (1) harapan pelanggan yang berfungsi sebagai pembanding atas suatu ukuran; dan (2) kepuasan pelanggan yang dikaitkan dengan kinerja produk. Mutu layanan akan berhasil dalam mencapai tujuannya jika konsumen merasakan kepuasan yang sangat tinggi dengan kata lain keberhasilan mutu layanan sangat tergantung pada konsumen atau pelanggan dalam arti lembaga yang bermutu selalu memberikan kepuasan kepada pelanggannya. Berbagai penelitian yang dilakukan berkenaan dengan mutu layanan menunjukkan bahwa ada keterkaitan antara mutu layanan dengan kepuasan dan loyalitas pelanggan. Semakin tinggi kualitas layanan yang diberikan, semakin tinggi tingkat kepuasan dan loyalitas pelanggan terhadap penyelenggara layanan

Schnaars dalam Susanto (2012;67) mengatakan bahwa"kepuasan pelanggan memberikan manfaat, diantaranya hubungan hubungan perusahaan dengan pelanggannya menjadi harmonis, memberikan dasar yang baik bagi pembelian berulang dan terciptanya loyalitas pelanggan serta membentuk suatu rekomendasi dari mulut ke mulut (word of mouth).Tuntutan yang diharapkan dari pelanggan adalah terjaminnya kualitas,baik akademik maupun administrative

Peningkatan mutu layanan pendidikan bukanlah suatu yang mudah, tidak mustahil dalam penyelenggaraannya sering menghadapi permasalahan.Rasa tidak puas dari para pelanggan, baik internal maupun eksternal sering muncul.Ketidakpuasan pelanggan ini menunjukkan bahwa penyelenggaraan layanan belum memenuhi ekspektasi dan harapan pelanggan. Prasetyo (2012) mengutip pendapat Wolkins yang mengemukakan bahwa ada enam factor yang menentukan kualitas pelayanan yaitu: organisasi, kepemimpinan, struktur organisasi, kemampuan aparat, system layanan dan penghargaan.

Dalam penelitian ini memfokuskan pada Sekolah Menengah Negeri 1 Ambawang Kabupaten kubu raya. Adapun pertimbangan memilih sekolah ini karena sudah banyak memiliki prestasi, baik di bidang akademik maupun non akademik.

Permasalahan yang muncul dalam penelitian ini adalah bagaimanakah kemampuan sekolah dalam memberikan layanan yang berkualitas pada Sekolah Menengah Atas (SMA) Negeri 1 Sungai Ambawang dengan focus penelitian ini adalah bagaimana mutu layanan pendidikan di Sekolah Menengah Atas Negeri 1 Sungai Ambawang.

Penelitian ini bertujuan untuk mengetahui gambaran tentang 1)Perencanaan mutu layanan , 2) Pelaksanaan layanan yang diberikan ,3) Pengendalian mutu layanan,4)Perbaiakan mutu layanan di SMA Negeri 1 Sungai Ambawang.

Secara teoritis hasil penelitian ini diharapkan dapat bermanfaat yaitu memberikan kontribusi yang berdaya guna, baik secara metodologis maupun empiris bagi kepentingan akademik dalam ilmu manajemen pendidikan khususnya dalam bidang mutu layanan.

Secara praktis hasil penelitian ini diharapkan bermanfaat untuk dijadikan sebagai bahan informasi bagi para pengelola pendidikan dalam upaya memperbaiki dan mengembangkan kinerja kepala sekolah dalam upaya memberilakn layanan yang bermutu di sekolah.

website: http://jurnal.untan.ac.id/index.php/jvip

email: jurnalvisi@untan.ac.id 
Mutu layanan sekolah yang dimaksud dalam penelitian ini adalah upaya pemenuhan kebutuhan dan kepuasan pelanggan serta kesesuaian ketepatan untuk memenuhi harapan pelanggan. Adapun aspek aspek yang berkenaan dengan mutu layanan antara lain: Perencanaan mutu layanan, pelaksanaan mutu layanan yang diberikan, pengendalian mutu layanan, serta perbaikan mutu layanan di SMA Negeri 1 Sungai Ambawang.

Mutu secara konseptual tidaklah mudah untuk didefinisikan karena bersifat subyektif. Beberapa ahli mutu yang mendefinisikan mutu sebagaimana dikutip poleh Martius (2016:8) sebagai berikut : 1)Juran: "fitness for use, us judged by the use". 2) Crosby : "conformance to customer requirement". 3) Feigenbaum : "the total omposite product and service characteristic marketing, enginering, manufacturing, and maintenance through which the product and service in use will meet the expectation of the cutomer". 4)Ishikawa :

"customer satisfaction".

Sedangkan Morgan dan Murgatroyd dalam Mukarom (2015:105) mengatakan bahwa "quality is the totality of a product services that bears on its ability to satisfy given needs". Kualitas merupakan bentuk-bentuk istimewa dari suatu produksi atau pelayanan yang mempunyai kemampuan untuk memuaskan kebutuhan customer. Berkenaan dengan bentuk istimewa ini.

Dalam konteks pendidikan, "mutu mencakup input, proses dan output pendidikan" (Zahrah,2014:28). Input pendidikan merupakan sesuatu yang dibutuhkan demi kelangsungan suatu proses. Proses merupakan perubahan sesuatu menjadi sesuatu lain, sedangkan output kinerja sekolah berupa prestasi yang dihasilkan sekolah. Sehingga mutu pendidikan mengutamakan keberadaan siswa. Oleh karena itu sekolah dituntut untuk melakukan proses yang baik. Tanpa proses yang baik, sekolah tidak akan mencapai mutu.

Menurut keputusan MENPAN Nomor 63 tahun 2004 ada empat kelompok jenis pelayanan. Berdasarkan keputusan MENPAN ini, pendidikan merupakan kelompok pelayanan jasa. Pelayanan jasa adalah pelayanan yang menghasilkan berbagai bentu kjasa yang dibutuhkan oleh publik.
Pelayanan atau jasa dalam istilah bahasa inggris adalah service, yang berasal dari kata kerja bahasa latin servire yang berarti mengabdi.

Donald dalam Hardiansyah (2011:10) mengemukakan pelayanan diartikan sebagai kegiatan atau manfaat yang ditawarkan oleh suatu pihak kepada pihak lain dan pada hakekatnya tidak berwujud serta tidak menghasilkan kepemilikan sesuatu, proses produksinya mungkin juga tidak dikaitkan dengan produk fisik".

Ivancevich, Lorenzi, Skinner dan Crosby dalam Ratminto, (2015:2) menyatakan bahwa "Pelayanan adalah produk-produk yang tidak kasat mata (tidak dapat diraba) yang melibatkan usaha-usaha manusia dan menggunakan peralatan".

Zemke dalam Ratminto (2015:3) menyatakan bahwa jasa pelayanan memil1ki karakteristik sebagai berikut: Konsumen memiliki kenangan, pengalaman atau memori tersebut tidak bisa di jual atau diberikan kepada orang lain, Tujuan penyelenggaraan pelayanan adalah keunikan. Setiap konsumen dan setiap kontak adalah special,Suatu pelayanan terjadi saat tertentu, ini tidak dapat disimpan digudang atau dikirimkan contohnya, Konsumen adalah rekanan yang terlibat dalam proses produksi, Konsumen melakukan kontrol kualitas dengan cara membandingkan harapan nya dengan pengalaman nya, Jika terjadi kesalahan , satu-satunya cara yang bisa dilakukan untuk memperbaiki adalah meminta maaf, Moral karyawan berperan sangat menentukan.

Menurut keputusan MENPAN Nomor 63 tahun 2004, sekurang-kurangnya ada enam standar pelayanan, berkenaan dengan prosedur pelayanan, waktu penyelesaian, biaya pelayanan, produk pelayanan, sarana dan prasarana serta kompetensi petugas pemberi pelayanan. Sebuah mutu sulit untuk dilakukan pengukuran.Oleh karena itu dalam melakukan penilaian tentang pelayanan yang berkualitas, mengalami kesulitan. Para ahli mengembangkan tolok sebagai pedoman untuk mengetahui bahwa pelaksanaan pelayanan itu berkualitas, sebagaimana dikemukakan Mukarom (2015:116) sebagai berikut:

website: http://jurnal.untan.ac.id/index.php/jvip email: jurnalvisi@untan.ac.id 
1) Menurut McDonald dan Lawton (1997)

Tolok ukur pelayanan menyangkut efisiensi dan efektifitas( Efficiency and effectiveness)

2) Menurut Salim dan Wordward (1992), tolok ukur meliputi ekonomi, efisiensi, efektivitas, dan keadilan ( Ekonomy, efficiency, effectiveness and accountability)

3) Menurut Lenvine (1990), tolok ukur pelayanan dapat dilihat dari segi responsivitas, responsibilitas, dan akuntabilitas (responsiveness, responsibility, dan accountability)

4) Menurut Zeithaml, Parasuraman dan Berry (1990), tolok ukur pelayanan ada sepuluh, yakni ketampakan fisik (tangibles), reliabilitas(reliability), responsivitas (responsiveness), kompetensi ( competence), kesopanan (courtessy), kredibilitas (credibility), keamanan (assurance), akses (acces), komunikasi (communication) dan pengertian (understanding).

Kualitas pelayanan dapat dilihat dari adanya kemampuan, pengetahuan, keterampilan yang baik yang dimiliki oleh penyedia layanan, berperilaku ramah, bersahabat, tanggap terhadap keinginan customer serta mau melakukan kontak atau hubungan pribadi dengan costumer serta mau melakukan kontak atau hubungan pribadi dengan costumer, bersikap jujur, bebas dari bahaya dan resiko. Pelayanan yang berkualitas harus memberi kemudahan untuk mengadakan kontak dan pendekatan, memiliki kemauan mendengarkan suara.keinginan dan aspirasi costumer sekaligus menyampaikan informasi dan melakukan segala segala usaha untuk mengetahui kebutuhan pelanggan.

Master dalam Mukarom (2015:113-114) mengemukakan beberapa hambatan dalam pengembangan manajemen kualitas, yaitu ketiadaan komiten dari manajemen, ketidakmampuan para penyelenggara layanan kultur yang mempengaruhi kualitas manajemen pelayanan pelanggan, ketiadaan pengetahuan manajemen kualitas para penyedia layanan, ketidaktepatan perencanaan yang dijadikan pedoman dalam pelayanan, pendidikan dan pelatihan yang berkelanjutan belum optimal, ketidakmampuan membangun learning organization, learning by the individuals dalam organisasi, ketidaksesuaian dalam struktur organisasi dan kebutuhan, ketidakcukupan sumber daya dan dana, ketidaktepatan dalam sistem penghargaan dan balas jasa bagi karyawan serta ketidaktepatan dalam memberikan perhatian pada pelanggan baik internal maupun eksternal.

Untuk meningkatkan calon pengguna jasa pendidikan, lembaga pendidikan perlu melakukan hal sebagai berikut : (a) Meningkatkan visualisasi jasa yang tidak berwujud menjadi berwujud; (b) Menekankan pada manfaat yang akan diperoleh (lulusan lembaga pendidikan); (c) Menciptakan atau membangun suatu nama merk lembaga pendidikan (education brand name); (d) Memakai nama seseorang yang sudah dikenal untuk meningkatkan kepercayaan pelanggan.

Jasa pendidikan yang diberikan sering berubahubah. Hal ini akan sangat tergantung kepada siapa yang menyajikannya, kapan, serta dimana disajikan jasa pendidikan tersebut. Oleh karena itu, jasa pendidikan sulit untuk mencapai kualitas yang sesuai dengan standar. Untuk mengantisipasi hal tersebut, lembaga pendidikan dapat melakukan beberapa strategi dalam mengendalikan kualitas jasa yang dihasilkan dengan cara sebagai berikut : (a) Melakukan seleksi dan mengadakan pelatihan untuk mendapatkan SDM jasa pendidikan yang lebih baik; (b) Membuat standarisasi proses kerja dalam menghasilkan jasa pendidikan dengan baik; (c) Selalu memonitor kepuasan peserta didik melalui sistem kotak saran, keluhan maupun survey pasar.

Jasa pendidikan tidak dapat disimpan dalam jangka waktu tertentu, sehingga tidak dapat dijual pada waktu mendatang. Karakteristik jasa ini bukan masalah, jika permintaan akan jasa tersebut stabil, karena jasa pendidikan mudah dalam persiapan pelayanannya. Jika permintaannya fluktuasi, lembaga pendidikan akan menghadapi masalah dalam mempersiapkan pelayanannya. Untuk itu diperlukan program pemasaran jasa yang sangat cermat, agar permintaan terhadap jasa pendidikan selalu stabil. Dengan melihat karakteristik tersebut jasa pendidikan diterima setelah melakukan interaksi dengan penghubung yang sangat dipengaruhi oleh siapa, kapan dan dimana jasa tersebut diproduksi.

website: http://jurnal.untan.ac.id/index.php/jvip

email: jurnalvisi@untan.ac.id 
Hal itu menjelaskan bahwa keberhasilan pendidikan akan sangat bergantung pada siapa, kapan dan dimana proses tersebut terlaksana.

Dalam jasa pendidikan, produk yang ditawarkan kepada siswa ialah reputasi, prospek dan variasi pilihan. Sekolah yang baik menawarkan reputasi mutu pendidikan yang tinggi, prospek bagi siswa setelah lulus dan pilihan konsentrasi berbagai program bervariasi sehingga calon siswa dapat memilih bidang yang sesuai dengan bakat dan minat mereka.

Produk secara umum merupakan segala sesuatu yang dapat ditawarkan produsen untuk diperhatikan, diminta, dibeli, digunakan atau dikonsumsi pasar sebagai pemenuhan kebutuhan atau keinginan pasar bersangkutan, Produk yang ditawarkan tersebut meliputi barang fisik, jasa organisasi dan ide. Produk dari sekolah adalah jasa kependidikan yang dapat dirinci atas : (Alma \& Hurriyati,2009:227-228)

1) Jasa kurikuler, meliputi : Kurikulum, Silabus Umum, rancangan bahan pembelajaran, penyajian bahan pembelajaran dan evaluasi.

2) Jasa penelitian, berupa berbagai penelitian dan hasilnya atau pengembangan kemampuan guru dalam meneliti dan membaca hasil penelitian.

3) Jasa ekstrakurikuler, meliputi berbagai kegiatan pelayanan di luar jasa kurikuler, seperti kegiatan kesenian, olahraga, prakarya dan lain-lain.

4) Jasa pengembangan kehidupan bermasyarakat, meliputi layanan untuk mengembangkan kemampuan para peserta didik untuk hidup bermasyarakat seperti mengobservasi kehidupan petani, pengusaha/ perusahaan industri, mengunjungi rumah sakit, mengunjungi rumah-rumah ibadah, panti asuhan dan memberi bantuan dan lain-lain.

5) Jasa administrasi/ketatausahaan, berupa layanan berbagai surat keterangan, surat pengantar bagi peserta didik, laporan hasil belajar.

6) Jasa layanan khusus, berupa layanan bimbingan dan konseling layanan perpustakaan, layanan usaha kesehatan sekolah, layanan kantin dan layanan transportasi atau bus.

Menurut Sutisna (1985:65) bentuk pelayanan yang ada dalam lembaga pendidikan ada dua, yaitu layanan pokok dan layanan bantu. Dalam memenuhi kebutuhan siswa yang berhubungan dengan pelayanan siswa di sekolah, kepala sekolah dibantu oleh para personil profesional sekolah diantaranya adalah :

a) Personil pelayanan pengajaran terdiri dari orang-orang yang bertanggung jawab pokoknya ialah mengajar, baik sebagai guru kelas, guru kegiatan ekstrakurikuler, tutor dan lain-lain.

b). Personil pelayanan administrasi, meliputi mereka yang mengarahkan, memimpin dan mengawasi personil lain dalam operasi sekolah serta bagian-bagiannya.

c). Personil pelayanan fasilitas sekolah, meliputi tenaga-tenaga di perpustakaan, pusat-pusat sumber belajar dan laboratorium bahasa, ahliahli teknik dan tenaga yang terlibat dalam fungsi mengajar atau fungsi melayani siswa.

d). Personil pelayanan murid atau siswa, meliputi pada spesialis yang tanggung jawabnya meliputi bimbingan dan penyuluhan, pemeriksaan psikologis dan kesehatan, nasehat medis dan pengobatan, testing dan penilitian, penempatan kerja dan tindak lanjut, serta koordinasi kegiatan murid.

Berdasarkan petunjuk direktorat Jendral Pendidikan Dasar dan Menengah (2005:12), pelayanan institusi pendidikan terbagi atas lima jenis, yaitu :a) Pelayanan administrasi pendidikan (administation services). b) Pelayanan pembelajaran (curriculum services). c) Pelayanan ko-kurikuler (co-curriculum services). d) Pelayanan penelitian (researches services) e) Pelayanan keinformasian pendidikan (information sistem services).

Kualitas pelayanan merupakan tahapan dimana spesifikasi konsumen dapat dipenuhi (Ruswanti,2012) Kualitas pelayanan diartikan sebagai tingkat keunggulan yang diharapkan dan pengendalian atas tingkat keunggulan tersebut untuk memenuhi keinginan pelanggan. Kualitas pelayanan bukanlah dilihat dari sudut pandang pihak penyelenggara atau penyedia layanan, 
melainkan berdasarkan persepsi masyarakat penerima layanan.

Kualitas pelayanan adalah totalitas karakteristik suatu konsep pelayanan yang mencakup seluruh aspek pelayanan dan tolak ukur kualitas pelayanan itu adalah dapat memberikan kepuasan kepada para pelanggan atau penerima layanan. Menurut Tjiptono (2005:5) mencakup pengertian kesesuaian dengan persyaratan, kecocokan untuk pemakaian, kecocokan untuk pemakaian, perbaikan berkelanjutan, bebas dari kerusakan/cacat, pemenuhan kebutuhan pelanggan sejak awal dan setiap saat, melakukan segala sesuatu secara benar dan sesuatu yang bisa membahayakan pelanggan.

\section{METODE PENELITIAN}

Bertolak dari focus masalah, tujuan penelitian, subjek penelitian dan karakteristik data yang akan dikumpulkan, maka desain yang tepat untuk penelitian ini analisis deskriptif dengan pendekatan kualitatif yang bersifat naturalistik dalam pengumpulan data.

Jenis penelitian ini adalah case studi (studi kasus) dengan melakukan secara eksploratif yang bersifat mendalam dengan menganalisis apa yang sebenarnya terjadi di balik fakta atau kasus. Adapun fakta atau kasus dalam penelitian ini adalah mengungkapkan manajemen mutu layanan. Sedangkan hasil penelitian ini berupa paparan gambaran mengenai suatu fenomena atau peristiwa.Penelitian akan dilaksanakan di Sekolah Menengah Atas (SMA) Negeri 1Sungai Ambawang.Terpilihnya SMA Negeri 1Sungai Ambawang sebagai tempat penelitian disebabkan sekolah tersebut merupakan sekolah yang berakreditasi A dan sekolah yang berprestasi.Sekolah ini juga telah banyak menghasilkan siswa yang berprestasi, baik prestasi akademik maupun non akademik.

Adapun waktu pelaksanaan dalam penelitian ini di mulai bulan Mei sampai dengan bulan September 2018.Sumber data dalam penelitian ini yaitu satu orang kepala sekolah dan para wakil kepala sekolah dan 3 orang guru serta dokumentasi sarana dan prasarana sekolah, termasuk dokumen administrasi sekolah. Sumber data dari kepala sekolah diambil untuk mendapatkan informasi primer tentang kegiatan yang dilakukannya sebagai seorang manajer.

Sementara sumber data sarana dan prasarana dijadikan sebagai sumber data sekunder untuk mendukung data primer sebagai bentuk bukti fisik, sedangkan sumber data dari guru dijadikan bahan sebagai konfirmasi tugas utamanya. Dalam penelitian kualitatif pengumpulan data dilakukan pada natural setting, sumber data primer, dan teknik pengumpulan data lebih banyak observasi partisipan, wawancara mendalam dan dokumentasi.Data yang diperoleh dari hasil wawancara dan catatan lapangan perlu dianalisis untuk mendapatkan suatu kesimpulan melalui generalisasi.Sejalan dengan itu Nasution $(2008 ; 89)$ mengatakan bahwa analisis data adalah proses mencari dan menyusun secara sistematis data yang diperoleh dari hasil wawancara, catatan lapangan dan dokumentasi dengan cara mengorganisasikan data ke dalam kategori, menjabarkan ke dalam unit-unit, melakukan sintesis, menyusun ke dalam pola, memilih mana yang penting dan akan dipelajari serta membuat kesimpulan, sehingga mudah dipahami oleh diri sendiri maupun orang lain.

Proses analisis data dalam penelitian secara deskriptif mengikuti langkah-langkah yang masih bersifat umum yaitu (1) reduksi data, (2) penyajian data, (3) penarikan kesimpulan dan verifikasi.

Keabsahan temuan dalam penelitian perlu dilakukan untuk menghindari kesalahan dalam menarik kesimpulan. Uji keabsahan data dalam penelitian kualitatif meliputi: uji kredibilitas data, uji transferability, uji depanability, dan uji confirmability (Sugiyono; 2008;122). Supaya keterpercayaan dan ketepatan data terjamin, maka peneliti melakukan dengan cara mendapatkan informan yang akurasi dan relevansinya sesuai antara data yang diperlukan dengan focus penelitian. Sementara untuk keabsahan data penelitian menggunakan cara snowball yaitu mengumpulkan data sebanyak mungkin sampai ditemukan makna yang utuh, mulai dari informan kunci berlanjut 
ke informan lain sesuai dengan petunjuk dan perkembangan data sebelumnya.

$$
\text { Berikutnya peneliti melakukan }
$$

trianggulasi, baik trianggulasi sumber, trianggulasi teknik maupun trianggulasi waktu yaitu untuk menguji kredibilitas data, dan untuk mengecek data yang diperoleh dari sumber yang sama dengan teknik yang berbeda serta waktu yang tepat dalam mengali informasi dari informan. Sebelum melakukan penelitian maka perlu dijadwalkan tahapantahapan sebagai berikut:Tahap persiapan, tahap kegiatan, lapangan tahap akhir.

\section{PEMBAHASAN}

Pengambilan data diawali dengan wawancara kepada semua pihak sekolah pada SMA Negeri I Sungai Ambawang antara lain Kepala Sekolah, Wakil-wakil Kepala Sekolah, dan Gurudan observasi, dokumentasi. Dari hasil wawancara dengan beberapa narasumber yaitu dengan wakil kepala sekolah bidang perlengkapan dan kesiswaan serta dua orang guru yang ada di SMA N 1 Sungai Ambawang, dapat diketahui bahwa aspek perencanaan mutu layanan di SMA N 1 Sungai Ambawang sudah cukup baik. Dari empat orang narasumber tersebut menyatakan bahwa dalam perencanaan visi misi, renstra, penyediaan sapras dan RAPBS mereka juga dilibatkan, meskipun tidak semuanya dilibatkan secara langsung, hal tersebut dikarenakan pihak sekolah memiliki tim khusus, namun setelah tim khusus selesai merancang atau merencanakan visi misi, renstra, penyediaan sapras dan RAPBS, para guru, staf dan komite di undang untuk mengambil keputusan yang akan digunakan dimasa yang akan datang. Visi sekolah merupakan representative dari keinginan dan harapan orang tua dan stake holder lainnya dalam mendidik putra putrinya di sekolah. Di samping itu visi akan menjadi kenyataan bilamana perencanaan yang dirumuskan itu jelas dan semua komponen sekolah dapat berkontribusi. Kepala Sekolah Menengah Atas Negeri 1 Sungai Ambawang yang baru dua tahun menjabat sebagai kepala sekolah masih berpegang pada visi yang dirumuskan oleh kepala sekolah yang lama, namun dalam pelaksanaannya sudah banyak kemajuan. Kepala sekolah juga telah banyak melibatkan dengan membentuk tim yang terdiri dari guru, wakilwakil kepala sekolah dalam menjabarkan visi tersebut ke dalam misi dan merumuskannya dalam program tujuan sekolah ke depannya melalui rapat koordinasi.

Sebagai tindak lanjut dari rumusan visi dan misi, maka kepala sekolah bersama tim membuat program untuk berbagai jenis kegiatan sekaligus menentukan waktu dan tempatnya. Di samping itu kepala sekolah juga mendorong agar guru,pegawai tata usaha dan lebih penting lagi wakil kepala sekolah agar senantiasa membuat program sesuai dengan bidangnya masing-masing yang dilakukan setiap tahun.

Berkenaan dengan program sekolah maka kepala sekolah mengajak para guru dan para wakil kepala sekolah serta sebagian tata usaha membentuk tim dan setiap orang dalam tim tersebut dapat memberikan saran/pendapat. Adapun program yang dibuat antara lain kerja sama dengan pihak kepolisian, dinas kedehatan, membuat program kelas unggul.

Pelayanan tidak hanya kepada siswa tetapi juga upaya kepala sekolah memberikan pelayanan kepada guru dan staf tata usaha.Sementara itu hasil wawancara dengan para guru dan wakil kepala sekolah bahwa mereka dilibatkan dalam merumskan visi dan misi sekolah karena bagi guru mereka sudah senior dan pernah menjabat wakil kepala sekolah.Sedangkan para wakil kepala sekolah harus dilibatkan karena mereka mengurus dan bertanggung jawab pada bidang masingmasing.

Para guru yang dilibatkan dalam merumuskan visi dan misi sekolah merasa sangat senang karena mereka diberi kesempatan untuk mengeluarkan pendapat/ide-ide yang dapat Demikian pula wawancara dengan para wakil kepala sekolah yang dilibatkan dalam menyusun program masing-masing dengan programnya.Wakil kepala sekolah di bidang kesiswaan dalam upaya memberikan pelayanan dengan membuat program pembinaan, baik spiritual, mental maupun keolahragaan dan kesenian. Begitu pula dengan wakil kepala sekolah di bidang sarana dan prasarana menyusun program tentang pengadaan peralatan sekolah.

website: http://jurnal.untan.ac.id/index.php/jvip

email: jurnalvisi@untan.ac.id 
Sementara itu wakil kepala sekolah di bidang kurikulum menyusun program.Aspek pelaksanaan, berdasarkan hasil wawancara peneliti dengan wakil kepala sekolah bidang perlengkapan dan kesiswaan serta dua orang guru, proses pelaksanaan mutu layanan sudah berjalan dengan baik, dari beberapa pertanyaan yang peneliti ajukan kepada narasumber tidak ada permasalahan yang signifikan.

Staf, guru, wakil kepala sangat kompak dan saling bahu membahu dalam melaksanakan tugas mereka. dari beberapa pertanyaan yang peneliti ajukan kepada guru yang menggambarkan bahwa aspek komunikasi disekolah ini cukup baik, profesionlitas antara kepala sekolah dan guru/staf sangat terlihat dari jawaban para guru, kepala sekolah sangat peka terhadapat apa yang menjadi keluhan para bawahanya. Melalui rapat tersebut kepala sekolah membahas apa yang menjadi keluhan yang dihadapi secara bersamasama. Kepala sekolah orang yang humble, responsif dan ramah, jika bertemu dengan para guru kepala sekolah tidak sungkan untuk menyapa duluan, bicaranya lembut namun lugas dalam menyampaikan sesuatu sehingga mudah dipahami, tidak memposisikan dirinya sebagai seorang pemimpin yang harus dihormati.

Dalam melaksanakan kegiatan, kepala sekolah menyampaikan berbagai informasi yang dilanjutkan dengan pengarahan sebagai upaya untuk mensosialisasikan. Oleh karena itu sebagai awal dari kegiatan tersebut maka kepala sekolah mengkomunikasikannya dengan menyampaikan melalui pengumuman atau surat edaran.

Layanan yang diberikan khususnya kepada pegawai tata usaha dengan cara menggali kesulitan yang dialami oleh yang bersangkutan. Selanjutnya dicari solusinya, baik secara bersamasama maupun sendiri-sendiri. Begitu pula layanan terhadap para guru terutama yang berhubungan dengan perangkat pembelajaran, masalah kemampuan guru dalam mengajar, masalah kesulitan guru dalam kenaikan pangkat juga tidak luput dari perhatian kepala sekolah dan berusaha melakukan berbagai pendekatan dengan memprioritaskan hal yang dianggap mendesak.

Berkenaan dengan kinerja pegawai tata usaha yang mengurus kepangkatan guru yang bekerjanya kurang memadai (lamban), maka kepala sekolah tidak langsung menegur, namun mencari penyebabnya, kemudian memberikan semangat jika memungkinkan diberikan reward.

Dalam memberikan layanan kepala sekolah juga memperhatikan waktu dan tempat pelaksanaannya sehingga tidak menggangu kegiatan yang lain. Karena apa yang dilakukan untuk memberikan pelayanan merupakan suatu hal yang cukup menyita waktu. Jika ada guru yang mengeluh tentang kurangnya sarana akademik, maka kepala sekolah berupaya mencari solusinya dan juga meminta pendapat dari guru yang bersangkutan.

Selama ini para guru maupun pegawai tata usaha merasa senang mendapat pelayanan dari kepala sekolah karena selalu diperlakukan sebagai tanaga yang professional. Menurut kepala sekolah para guru terutama guru senior bersemangat bekerja sesuai dengan arahan dari beliau, begitu pula denga pegawai tata usaha belum ada keluhan yang berat.

Upaya kepala sekolah dalam menyampaikan berbagai informasi dilakukan melalui pertemuan atau rapat. Dari aspek pengawasan kepala sekolah sangat memperhatikan aspek ini, hal ini terlihat dari jawaban atas pertanyaan peneliti kepada guru dan wakil kepala sekolah yang penelti wawancara, salah satu informasi yang peneliti dapat iyalah kepala sekolah melakukan supervisi serta meminta laporan hasil kerja guru dan wakil kepala sekolah. Hasil kerja guru dan wakil kepala sekolah tersebut menjadi bahan evaluasi kepala sekolah jika memang dirasa ada yang harus di evaluasi. Dan jika dari hasil evaluasi tersebut terdapat guru yang memiliki kesulitan maka wakil kepala sekolah memberikan masukan dan bimbingan agar bisa diselesaikan, jika permasalahanya memang berat maka kepala sekolah akan mengambil alih dan mengadakan rapat untuk menyelesaikan kesulitan tersebut.

Dalam suatu organisasi atau lembaga yang sangat diperhatikan adalah pengendalian yaitu suatu upaya untuk menghindari terjadinya penyimpangan atau dengan kata lain pelaksanaan berjalan sesuai dengan arahan. Melalui pengendalian diharapkan semua program yang telah direncana kan berjalan dengan baik sesuai

website: http://jurnal.untan.ac.id/index.php/jvip

email: jurnalvisi@untan.ac.id 
dengan tugas pokok dan fungsi masing-masing. Fungsi pengendalian dunia pendidikan, yaitu berfungsi untuk menghindari terjadinya penyimpangan atau penyalahgunaan dalam memproduksi lulusan.

Kemampuan kualitas lulusan artinya memenuhi kebutuhan yang dapat diterima dan bersaing secara global, dengan kata lain kualitas kemampuan lulusan harus sesuai dan memenuhi tuntutan pengguna. Oleh karena itu kepala sekolah diposisikan sebagai perencana, pengarah, fasilitator, motivator, evaluator, tetapi tidak sebagai operator.Kegiatan pengendalian dilakukan sebelum dan saat rencana dibuat, sedangkan kegiatan evaluasi dilakukan setelah implementasi rencana. ,

Proses pengendalian yang dilakukan sekolah disampaikan kepala para guru bahwa sekolah melakukan evaluasi dengan tujuan untuk mengetahui lancar tidaknya suatu kegiatan tertentu. Dengan demikian dapat dikatakan bahwa pengendalian yang dilakukan oleh kepala sekolah sudah memadai, meskipun masih ada yang perlu di perbaiki.Diantara ciri manajemen mutu terpadu adalah perbaikan kontinu yaitu perbaikan berulang pada berbagai ukuran, baik perubahan kecilmaupun perubahan terobosan. Sedangkan kegiatan inti yang dilakukan dalam proses perbaikan berupa penyusunan rencana tindak lanjut yang berisi tentang penjelasan hasil rekomendasi dari proses penilaian yang dilakukan dalam proses pengendalian.

Perbaikan mutu layanan merupakan proses perbaikan kualitas secara berkesinambungan melalui kegiatan identifikasi proses dan metode, pembentukan tim yang bertanggung jawab atas proyek perbaikan tertentu serta menyediakan sumber daya dan pelatihan (Nasution; 2004;197).

Beberapa tipe perbaikan yang dilakukan sekolah sebagai lembaga pendidikan seperti peningkatan nilai pendidikan pada siswa melalui pengembangan layanan baru pendidikan, mengurangi ketidakkonsistenan yang membuat kredibilitas proses pendidikan dipertanyakan, memperbaiki cara menanggapi tuntutan siswa serta memperbaiki produktivitas dan efektivitas penggunaan semua sumber daya (Arcaro; 2007; 25).
Berdasarkan informasi yang di dapat bahwa di SMA Negeri 1 Sungai Ambawang melibatkan semua pihak dalam proses pendidikan mulai dari kepala sekolah, para wakil kepala sekolah, dewan guru, para staf tata usaha serta kolmite sekolah. Bahkan pengawas dan dinas kabupatenpun terlibat dalam pelaksanaan, agar semua rencana yang dibuat dapat didukung oleh semua pihak.

Berdasarkan hasil wawancara bahwa kepala sekolah terus menerus melakukan perbaikan terutama yang berhubungan dengan proses pembelajaran. Karena pembelajaran merupakan kebutuhan yang harus dipenuhi tuntutannya agar prestasi siswa semakin meningkat. Di samping itu kepala sekolah juga berupaya memenuhi kebutuhan sarana dan prasarana karena dengan sarana dan prasarana yang memadai sangat menunjang dalam upaya meningkatkan prastasi, baik akademik maupun non akademik.

\section{KESIMPULAN DAN SARAN Kesimpulan}

Perencanaan dalam memberikan pelayanan oleh SMA Negeri 1 Sungai Ambawang dengan meneruskaan visi dan misi terdahulu, kemudian membuat program kerjasama dalam pembinaan siswa.Semua program yang dibuat selalu melibatkan sebagian guru dan staf tata usaha serta semua wakil kepala sekolah.2.Mutu layanan yang dilaksanakan oleh Kepala sekolah berupa pembinaan kepada guru, staf TU dan siswa, baik akademik maupun non akademik. Adapun cara layanan yang dilakukan dengan memprioritaskan kegiatan utama namun tidak mengabaikan kegiatan yang lainnya. 3. Pengendalian mutu dalam memberikan pelayanan dengan menyiapkan perangkat audit evaluasi. 4. Perbaikan mutu layanan pendidikan dilakukan dengan penyusunan tindak lanjut.

\section{Saran}

Hasil rekomendasi dari penilaian yang dilakukan dalam proses pengendalian yaitu berupa perbaikan proses, metode, serta perbaikan pemberdayaan sumber daya dan pelatihan.Beberapa saran ini di sampaikan kepada pihak-pihak antara lain:Bagi kepala sekolah sebaiknya dalam memberikan pelayanan diikuti

website: http://jurnal.untan.ac.id/index.php/jvip

email: jurnalvisi@untan.ac.id 
pula dengan penilaian setiap kegiatan. Bagi guru sebagai tenaga professional dalam membantu dan sebagai pendamping kepala sekolah sebaiknya tidak banyak ketergantungan kepada kepala sekolah

\section{DAFTAR RUJUKAN}

Alma, Buchori \& Hurriyati, 2009, Manajemen Corporate \& Strategi Pemasaran Jasa Pendidikan, Bandung, Alfabeta

Depdiknas, 2004, Manajemen Mutu Berbasis Sekolah, Jakarta: Dirjen Dikdasmen

Diana A dan Tjiptono F , 2003, Total Quality Management, Yogyakarta: Penerbit Andi

Fattah, Nanang, 2004, Landasan Manajemen Pendidikan, Bandung: Remaja Rosda Karya Hardiyansyah, 2011, Kualitas Pelayanan Publik, Jogyakarta, Gava Media

Martinus, Tukiran, 2016, Membangun Sistem Manajemen Mutu Berdasarkan ISO 9001;2015 Yogyakarta; Leutika Nouvalitera
Mukarom, Zainal, 2015, Manajemen Pelayanan Publik, Bandung, CV. Pustaka Karya Muhammad Nur Nasution, 2004, Manajemen Mutu Terpadu, Bogor, Galia Indonesia

Nikmah, 2013, Pengorganisasian Layanan Pendidikan Boarding School Berorientasi Mutu, http/journal unnes.ac.ac.id/sju/index.php/eduman

Purnama, Nursya'bani, 2006, Manajemen Kualitas Prespektif Global, Yogyakarta: EKONISIA

Ratminto dkk, 2015, Manajemen Pelayanan, Jogyakarta, Pustaka Pelajar

Sartika Ikke Dewi, 2002, Quality Service In Education. Edisi Khusus Untuk Kalangan Mahasiswa, Bandung: Kantor Yayasan Potensia.

Imam,Gunawan, Kualitas Pelayanan Pendidikan, 05 November 2012.

(http://masimamgun.blogspot.co.id/2012/11 /kualitas-pelayanan-pendidikan.html, diakses 01 April 2016.) 